Lynn Waterhouse

Trenton State College

Niles Newton

Northwestern University Medical School

\title{
REFERENCES
}

Bauman, M., \& Kemper, T. (1985). Histoanatomic observations of the brain in early infantile autism. Neurology, 35, 866-874.

Bicknell, R. J., Leng, G., Lincoln, D. W., \& Russell, J. A. (1988). Nalaxone excites oxytocin neurones in the supraoptic nucleus of lactating rats after chronic morphine treatment. Journal of Physiology, 396, 297-317.

Chamberlain, R. S., \& Herman, B. (1990). A novel biochemical model linking dysfunctions in brain melatonin, proopiomelanocortin peptides, and serotonin and autism. Biological Psychiatry, 28, 773-793.

Insel, T. (in press). Oxytocin: A neuropeptide for affiliation-Evidence from behavioral, receptor autoradiographic, and comparative studies. Psychoneuroendocrinology.

Kawarabayashi, T., Izumi, H., Ikeda, M., Ichihara, J., Sugimori, H., \& Shirakawa, D. (1990). Modification by magnesium of the excitatory effect of oxytocin in electrical and mechanical activities of pregnant human myometrium. Obstetrics and Gynecology, 76, 183-188.

Modahl, C. (1992). Does oxytocin mediate social deficits in childhood attachment disorders? Master's thesis, Division of Medical Sciences, Boston University.

Newton, N. (1973). Interrelationships between sexual responsiveness, birth, and breastfeeding. In J. Zubin \& J. Money (ed.), Contemporary sexual behavior: Critical issues in the 1970s (pp. 77-98). Baltimore, MD: Johns Hopkins University Press.

Rimland, B. (1988). Controversies in the treatment of autistic children: Vitamin and drug therapy. J. Child Neurology, 3, (Suppl.), s68-s72.

Sahley, T. L., \& Panksepp, J. (1987) Brain opioids and autism: An updated analysis of possible linkages. Journal of Autism and Developmental Disorders, 17, 201-216.

Sandman, C. A., Barron, J. L., DeMet, E. M., Chicz-deMet, A., Rothenberg, S. J., \& Zea, F. J. (1990). Opioid peptides and perinatal development: Is B-endorphin a natural teratogen? Annals of the New York Academy of Sciences, 579, 91-108.

\section{CORRECTION TO PREVIOUS EVALUATION OF FACILITATED COMMUNICATION}

Since publication of my personal evaluation of Facilitated Communication (Bettison, 1991), I have had some communication both with Rosemary Crossley of the DEAL Centre in Melbourne, Victoria, and with Annie McDonald. While their reaction to my comments was generally positive, McDonald was most unhappy with my references to her. She has asked me to bring the following information, not originally available to me, to the attention of $\mathrm{JADD}$ readers. 
McDonald's visit to the South Australian Centre for Crippled Children, referred to in my evaluation, was for a wheelchair and switch assessment, not a communication assessment. She informs me that she underwent two assessments of her ability to read, carried out by psychologists in 1977 and 1978, using procedures in which neither the assessor nor the facilitator knew the answers to questions put to her. These established that she had reading skills. She also informed me of two assessments by psychologists in 1979 using subtests of the WAIS with facilitation and the Peabody Picture Vocabulary Test without facilitation. On the basis of these results, the Supreme Court of Victoria judged that she had the capacity to make decisions for herself and to manage her own affairs.

McDonald is currently completing the final year of her university studies for a degree in humanities. She intends visiting the United States later this year. Her concern is that those she meets during her visit accept her as she is, without any preconceptions that may have been engendered inadvertently by my earlier letter.

However, the value or otherwise of Facilitated Communication for people with autism remains unanswered until independent scientific evidence is available about facilitator influence and treatment outcomes. At least one formal clinical evaluation has begun in Australia. Information about the evaluation can be obtained from Tony Attwood, Intellectual Disability Services, P.O. Box 806, Brisbane, Queensland 4001, Australia, Telephone (07) 224-4964 (visitors and requests for information are welcome).

Sue Bettison, Chief Executive Officer Autistic Association of New South Wales

Box 361

Forestville, N.S.W. 2087 Australia

\section{REFERENCE}

Bettison, S. (1991). Informal evaluation of Crossley's facilitated communication [Letter to the editor]. Journal of Autism and Developmental Disorders, 21, 561-563.

\section{THE PREVALENCE OF RETT SYNDROME AND INFANTILE AUTISM IN CHIKUGO DISTRICT, THE SOUTHWESTERN AREA OF FUKUOKA PREFECTURE, JAPAN}

Rett syndrome (RS) is well known as one of the mental disorders with autistic behavior. The prevalence of RS is thought to be approximately 